\title{
Self-Directed Learning in EFL During Covid-19 Pandemic: Teacher's Perception and Students' Learning Autonomy
}

\author{
N. L. M. P. Adi ${ }^{1 *}$, L. P. Artini², L. G. E. Wahyuni ${ }^{3}$ iD \\ 1,2,3 Jurusan Bahasa Asing, Universitas Pendidikan Ganesha, Singaraja, Indonesia \\ *Corresponding author: niluhmadepurniaadi10@undiksha.ac.id
}

\begin{abstract}
Abstrak
Akibat merebaknya penyakit virus corona (COVID-19) secara global, peraturan baru mewajibkan siswa untuk belajar dari rumah sehingga siswa harus bisa belajar secara mandiri. Penelitian ini bertujuan untuk menganalisis persepsi guru tentang self-directed learning (SDL) dan komponen SDL yang dapat diidentifikasi dari kegiatan pembelajaran online yang ditugaskan oleh guru selama pandemi COVID-19. Penelitian ini dirancang dalam bentuk penelitian embedded mixedmethod. Seorang guru bahasa Inggris di sebuah sekolah menengah dipilih sebagai peserta. Selanjutnya, data dikumpulkan melalui angket, observasi, dan tabel klasifikasi. Hasil penelitian menunjukkan bahwa: 1) dengan skor 4,00, guru mempersepsikan dirinya "berpengetahuan" tentang pengetahuan SDL, dengan skor 3,57, guru mempersepsikan dirinya "diharapkan" atau sering melaksanakan kegiatan pembelajaran yang mendukung SDL, dengan skor dari 3,88, guru menilai dampak SDL sebagai "berpengaruh" pada siswa, 2) komponen SDL tercermin melalui kegiatan pembelajaran online yang ditugaskan oleh guru adalah "mengembangkan rasa memiliki siswa dalam belajar" dan "mengembangkan self-monitoring siswa" dan manajemen diri." Dengan demikian, guru mempersepsikan SDL secara positif, dan ada dua komponen SDL yang dipromosikan oleh aktivitas pembelajaran online guru.
\end{abstract}

Kata kunci: Self-Directed Learning (SDL), Persepsi Guru, Kegiatan Belajar Online

\section{Abstract}

Due to the global outbreak of coronavirus disease (COVID-19), new regulations require students to study from home so that students must be able to study independently. This study aimed to analyze teachers' perceptions of self-directed learning (SDL) and SDL components that can be identified from online learning activities assigned by teachers during the COVID19 pandemic. This research was designed in the form of embedded mixed-method research. An English teacher at a high school was selected as a participant. Furthermore, data were collected through questionnaires, observations, and classification tables. The results showed that: 1) with a score of 4.00 , teachers perceive themselves as "knowledgeable" about SDL knowledge, with a score of 3.57, teachers perceive themselves as "expected" or often carry out learning activities that support SDL, with a score of 3.88, teachers assessing the impact of SDL as "influential" on students, 2) components of SDL reflected through online learning activities assigned by the teacher are "developing a sense of belonging to students in learning" and "developing student self-monitoring" and self-management." Thus, teachers perceive SDL positively, and there are two components of SDL promoted by teachers' online learning activities.

Keywords: Self-Directed Learning (SDL), Teacher's Perception, Online Learning Activities

\begin{tabular}{|c|c|c|}
\hline \multicolumn{2}{|l|}{ History: } & Publisher: Undiksha Press \\
\hline Received & February 11, 2021 & Licensed: This work is licensed under \\
\hline Revised & March 30, 2021 & a Creative Commons Attribution 3.0 License \\
\hline Accepted & April 4, 2021 & (c) (9) () \\
\hline Published & : April 24, 2021 & (2) ${ }_{E Y} S_{S A}$ \\
\hline
\end{tabular}

\section{Introduction}

In this 21st century era, students are seen as 21st-century learners who are independent, self-determining (Andrian \& Rusman, 2019; Hirschman \& Wood, 2018; Tan \& Koh, 2014). It means that students are required to develop their independence and be more independent in learning. Self-directed learning is a process in which students take the initiative to identify their learning needs, formulate learning objectives, determine learning resources, apply appropriate learning strategies and evaluate their learning outcomes, with or without the help of others (Hill et al, 2020; Suryadewi, Wiyasa, \& Sujana, 2020). In March 2020, due to the coronavirus disease (COVID-19) global outbreak, the Indonesian Ministry of Education and Culture issued a new regulation requiring students to study from home. It is 
stated that the teaching and learning process must be carried out online during this pandemic. This condition can be a good opportunity for students to develop SDL (Hanik, 2020). In this condition, students need to raise their awareness to manage and monitor their learning. They must take the initiative to catch up on learning without expecting direct help from the teacher. This urgency is also a reason for teachers to carry out online learning activities that can advance SDL and increase student independence. Teachers have the responsibility to facilitate and guide the development of students' SDL abilities (Tjakradidjaja et al., 2016)

SDL is important in facing this 21 st-century era. This learning allows students to experience a sense of self-awareness to master a certain piece of knowledge and then slowly begin to manage the learning process (Van der Walt, 2016). This kind of experience is useful in building lifelong learning habits (Devi et al, 2016; Hill et al., 2020). Lifelong learning skills are very important in the 21st century because humans must learn throughout their lives to survive in a global society. (Daggol, 2017; Timpau, 2015). Another reason is that SDL encourages students to be responsible. When students practice SDL, they actively participate in reading learning materials, completing assigned tasks, planning lessons, and evaluating learning milestones (Geng, Law, \& Niu, 2019). This learning helps students to recognize their responsibilities and develop them to become responsible people. To survive in the world of 21st-century work, an individual must take responsibility and know how to handle accountability Brandt (2020). In addition, SDL can also affect the development of students' 21 st-century learning skills, which consist of collaboration, communication, creativity, and critical thinking (Devi et al., 2016; Geng et al., 2019; Hill et al., 2020; Van et al, 2019). This learning provides autonomy that can encourage them to do so. Therefore, the application of SDL is important for students to be able to face the demands of the 21 st century.

Concerning learner autonomy, SDL is often a humanistic approach that produces learner autonomy in learning. Learner autonomy can be defined as the capacity of students to control their learning (Benson, 2016). SDL provides a set of skills that contribute to student autonomy (Curry et al, 2017; Yuli Asni, 2019). Through SDL, students can be more independent in setting learning goals, making lesson plans, determining learning resources, identifying learning strategies, assessing learning outcomes, and so on. Other studies also argue that SDL can be the best method to develop students' independence (Gharti, 2019). Many kinds of literature present strategies to increase learner autonomy which are closely related to SDL strategies. It can be concluded that students who are independent in learning have a greater capacity to control their learning and manage their autonomy.

Several studies have been conducted to add insight into SDL. Studies conducted to explore students' perspectives on SDL outside the classroom found that most students can be considered to have moderate self-direction Humaira and Hurriyah (2018). However, they experienced some difficulties in determining appropriate learning strategies, evaluating learning, and doing self-reflection. Previous research has also shown that EFL students have positive attitudes towards SDL Shaalan (2019). However, many of them face some problems understanding the nature of self-learning and practicing it effectively. Similarly, another study showed that EFL students had positive perceptions of SDL Gharti (2019). They view SDL as a necessary learning strategy that can help them become more independent in learning.

Other research findings show that SDL is moderately and positively correlated with online learning Durnali (2020). It implies that SDL has an important role in creating successful online learning and online learning can be a positive medium for SDL development. Zhu et al. (2020) also noted that promoting SDL components such as selfmotivation, self-management, and self-monitoring in online classrooms is very important because they can impact learning achievement and engagement. From previous studies, it can be said that students perceive SDL positively. Especially about online learning, SDL can 
affect learning success because the two things are positively correlated. However, the study mainly focused on students' perceptions of SDL. None of the studies described how teachers viewed self-directed learning and how teachers could promote SDL in the teaching and learning process. Therefore, this study aimed to analyze teachers' perceptions of self-directed learning (SDL) and the identifiable components of SDL from online learning activities assigned by teachers during the COVID-19 pandemic. The participant of this study was an English teacher at the selected high school. In EFL teaching and learning, students trained to be independent will acquire and master the language more easily because they use the initiative to learn language independently and independently (Vu \& Shah, 2016).

\section{Methods}

This research was designed in the form of embedded-mixed method research because it requires qualitative and quantitative data. This research took place in a public high school located in Badung Regency. An English teacher at the school was selected to be a participant in the study. In collecting data, three instruments were used, self-rated questionnaires, observation sheets, and classification tables. The self-rated questionnaire was developed by adopting the SDL theory proposed by Tan and Koh (2014), given to English teachers to collect data on teachers' perceptions of SDL. The Blueprint of the Self-Rated instrument can be seen in the following Table 1.

Table 1. Blueprint of Self-Rated Questionnaire

\begin{tabular}{|c|c|c|c|c|}
\hline $\begin{array}{l}\text { SDL } \\
\text { Components } \\
\text { by Tan and } \\
\text { Koh }(\mathbf{2 0 1 4}) \\
\end{array}$ & Indicators & $\begin{array}{c}\text { Items for } \\
\text { Knowledge } \\
\text { Aspect }\end{array}$ & $\begin{array}{c}\text { Items for } \\
\text { Implementation } \\
\text { Aspect }\end{array}$ & $\begin{array}{c}\text { Items } \\
\text { for } \\
\text { Impact } \\
\text { Aspects }\end{array}$ \\
\hline $\begin{array}{l}\text { Developing } \\
\text { students' }\end{array}$ & $\begin{array}{l}\text { a. Providing learners' } \\
\text { autonomy in task design }\end{array}$ & 1,2 & $\begin{array}{l}1,2,3,4,5 \\
6,7\end{array}$ & 1 \\
\hline $\begin{array}{l}\text { ownership of } \\
\text { learning }\end{array}$ & $\begin{array}{l}\text { b. Involving students in } \\
\text { identifying learning gaps }\end{array}$ & 10 & 8,9 & 2 \\
\hline & $\begin{array}{l}\text { c. Facilitating students' } \\
\text { investigative inquiry, goal } \\
\text { setting and planning }\end{array}$ & 9,11 & 10,11 & 3,4 \\
\hline $\begin{array}{l}\text { Developing } \\
\text { students' }\end{array}$ & $\begin{array}{l}\text { a. Providing scaffolds for } \\
\text { students' self- monitoring }\end{array}$ & 6,8 & $12,13,14,15$ & 5 \\
\hline $\begin{array}{l}\text { self- } \\
\text { management } \\
\text { and self- } \\
\text { monitoring }\end{array}$ & $\begin{array}{l}\text { b. Monitoring students' } \\
\text { learning and provide just- } \\
\text { in-time assistance }\end{array}$ & 3 & $\begin{array}{l}16,17,18 \\
19,20,21 \\
22,23\end{array}$ & 6 \\
\hline $\begin{array}{l}\text { Provides } \\
\text { opportunity }\end{array}$ & $\begin{array}{l}\text { a. Engaging the students in } \\
\text { reflection of learning }\end{array}$ & 7 & 24 & 7 \\
\hline $\begin{array}{lr}\text { for } & \text { the } \\
\text { students } & \text { to }\end{array}$ & $\begin{array}{l}\text { b. Engaging the students' } \\
\text { prior knowledge }\end{array}$ & 5 & $25,26,27$ & 8 \\
\hline $\begin{array}{l}\text { extend their } \\
\text { learning }\end{array}$ & $\begin{array}{l}\text { c. Allowing the students to } \\
\text { make connections of what } \\
\text { they learn in and out of } \\
\text { school }\end{array}$ & 4 & 28 & 9 \\
\hline Total Items & & 11 & 28 & 9 \\
\hline
\end{tabular}


As shown in Table 1, perception consists of three aspects, knowledge (how teachers perceive their knowledge of SDL), implementation (to what extent do teachers apply SDL in their opinion), and impact (how teachers see the impact of SDL on students). Five choices with a score of 1 to 5 are provided for each statement. At the same time, the observation sheet was used to collect data about online learning activities assigned by teachers during the COVID-19 pandemic. Observations were made by attending online learning meetings conducted by the teacher until the data obtained were saturated. The Learning Management System (LMS) used by the teacher is Google Classroom. Meanwhile, the classification table was used to identify the SDL components promoted by the online learning activities assigned by the teacher. The results of the self-rated questionnaire were categorized as quantitative data to analyze the results. For each aspect, the scores of all statements were added up and then entered into the score formula (perception aspect). Then, the final score calculation was used to categorize teachers' perceptions of these aspects. In interpreting the final score, the Likert scale proposed by Sugiyono (2015) was adapted. Likert scale adaptations are presented in the following Table 2 .

Table 2. Likert Scales Used to Interpret Teacher's Perception

\begin{tabular}{|c|c|c|c|}
\hline $\begin{array}{c}\text { Criteria of } \\
\text { Perception on } \\
\text { Knowledge of } \\
\text { SDL } \\
\end{array}$ & $\begin{array}{c}\text { Criteria of Perception on } \\
\text { the Implementation of } \\
\text { SDL }\end{array}$ & $\begin{array}{l}\text { Criteria of } \\
\text { Perception on the } \\
\text { Impact of SDL }\end{array}$ & Score \\
\hline $\begin{array}{l}\text { Unlikely } \\
\text { Knowledgeable }\end{array}$ & Unlikely Anticipated & $\begin{array}{c}\text { Unlikely } \\
\text { Influential }\end{array}$ & $1.00 \leq x \leq 1.50$ \\
\hline $\begin{array}{l}\text { Slightly } \\
\text { Knowledgeable }\end{array}$ & Slightly Anticipated & $\begin{array}{l}\text { Slightly } \\
\text { Influential }\end{array}$ & $1.50<x \leq 2.50$ \\
\hline $\begin{array}{l}\text { Moderately } \\
\text { Knowledgeable }\end{array}$ & Moderately Anticipated & $\begin{array}{l}\text { Moderately } \\
\text { Influential }\end{array}$ & $2.50<x \leq 3.50$ \\
\hline Knowledgeable & Anticipated & Influential & $3.50<x \leq 4.50$ \\
\hline $\begin{array}{l}\text { Very } \\
\text { Knowledgeable }\end{array}$ & Very Anticipated & Very Influential & $4.50<x \leq 5.00$ \\
\hline
\end{tabular}

As shown in Table 1, there are five criteria for each aspect of perception. Each criterion has its score range. By looking at the score obtained by the teacher and the range of scores in table, teacher's perception of each aspect is interpreted. The results of the observation sheet are classified as qualitative data and analyzed descriptively. In each meeting or observation, the activities carried out by the teacher are regulated, whether including pre, temporary, or post activities. Then it is described and interpreted to see if there are general indications of SDL in these activities. The results of the classification table are also analyzed descriptively because they can be said to be qualitative data. The data in this classification table is closely related to the data from the observations. The activities that have been observed are analyzed and described, whether they support or reflect certain SDL components and indicators in the theory of Tan and Koh (2014).

\section{Results and Discussion}

In this study, teachers' perceptions were divided into three parts, perceptions of SDL content knowledge, perceptions of SDL implementation, and perceptions of the impact of SDL on students. The following table presents the final scores obtained by teachers after responding to self-rated questionnaires. 
Table 3. The Classification of Teacher's Perception

\begin{tabular}{clcc}
\hline No & Aspect of Perception & Score Obtained by the Teacher & Criteria \\
\hline 1 & Knowledge of SDL & 4.00 & Knowledgeable \\
2 & Implementation of SDL & 3.57 & Anticipated \\
3 & Impact of SDL & 3.88 & Influential \\
\hline
\end{tabular}

As shown in Table 3, the final score of teachers' perceptions of SDL knowledge is 4.00 Adaptation of the Likert scale of Sugiyono (2015). This score indicates that the teacher assesses himself as knowledgeable and aware of the importance of SDL. In the questionnaire, teachers generally agree that SDL is important for students, especially in this 21 st century. He agrees that SDL can give autonomy to students in learning and increase students' initiative in monitoring their learning. Moreover, he strongly agrees that SDL can be done anytime and anywhere. For the implementation aspect, the final score obtained by the teacher is 3.57 . This score indicates that teachers perceive themselves to be anticipated in implementing SDL strategies based on Tan and Koh (2014). The strategy includes three components such as developing student ownership in learning, developing student self-management and selfmonitoring, and providing opportunities for students to expand their learning. In other words, the teacher assumes that they have implemented most of the SDL strategies, although not continuously.

In the third aspect, the impact of SDL, the final score obtained by the teacher is 3.88 . This score indicates that teachers perceive the impact of SDL on students. In the questionnaire for statements related to developing students' sense of belonging in learning, teachers felt that SDL strategies could significantly motivate students in learning, stimulate them to recognize their learning goals, and assist them in determining appropriate sources and ways of learning. However, the teacher saw a moderately significant impact on students' activeness when he involved them in task design. For statements related to the development of self-management and self-monitoring of students, the teacher considered the strategy to increase students' initiative in monitoring their learning. In addition, teachers feel that the use of LMS helps them in monitoring student learning flexibly. Statements that have to provide opportunities for students to expand their learning, teachers feel that strategies can help students identify and overcome their weaknesses in learning. Connect their previous knowledge with their new knowledge, and connect their knowledge with real-life situations. After giving the questionnaire, observations were made to see online learning activities provided by the teacher during the COVID-19 pandemic. The results of the observations can be seen in the following Table 4.

Table 4. Online Learning Activities Assigned by the Teacher

\begin{tabular}{|c|c|c|}
\hline $\begin{array}{c}\text { Observation } \\
\text { Date }\end{array}$ & Lesson Segment & Activities Assigned by Teacher \\
\hline Observation 1; & Pre-activity & 1. The students filled the attendance list \\
\hline October 2,2020 & Whilst- activity & $\begin{array}{l}\text { 2. The students watched video about } \\
\text { biographical recount text } \\
\text { 3. The students made a biographical recount text }\end{array}$ \\
\hline & Post-activity & 4. - \\
\hline Observation 2; & Pre-activity & 1. - \\
\hline October 16,2020 & Whilst-activity & $\begin{array}{l}\text { 2. The students watched video about "modal: } \\
\text { should" } \\
\text { 3. The students did a discussion regarding the } \\
\text { material by asking and answering each other }\end{array}$ \\
\hline
\end{tabular}




\begin{tabular}{|c|c|c|}
\hline $\begin{array}{c}\text { Observation } \\
\text { Date }\end{array}$ & Lesson Segment & Activities Assigned by Teacher \\
\hline \multirow{4}{*}{$\begin{array}{l}\text { Observation } 3 \\
\text { November } 6 \\
2020\end{array}$} & Post-activity & $\begin{array}{l}\text { questions } \\
\text { 4he students were asked to feel free to ask } \\
\text { more questions outside of the class hours }\end{array}$ \\
\hline & Pre-activity & 1. - \\
\hline & Whilst-activity & $\begin{array}{l}\text { 2. The students did an assignment about } \\
\text { advertisement text }\end{array}$ \\
\hline & Post-activity & 3. - \\
\hline \multirow{3}{*}{$\begin{array}{l}\text { Observation } 4 \\
\text { November } 13 \\
2020\end{array}$} & Pre-activity & 1. The students filled the attendance list \\
\hline & Whilst-activity & $\begin{array}{l}\text { 2. The students found the generic structure of a } \\
\text { song lyric }\end{array}$ \\
\hline & Post-activity & 3. - \\
\hline \multirow{3}{*}{$\begin{array}{l}\text { Observation } 5 \\
\text { November } 20 \\
2020\end{array}$} & Pre-activity & 1. The students filled the presence list \\
\hline & Whilst-activity & $\begin{array}{l}\text { 2. The students read the material provided about } \\
\text { song lyric }\end{array}$ \\
\hline & Post-activity & 3. - \\
\hline
\end{tabular}

Based on Table 4, in each meeting, the online learning activities provided by the teacher were classified into pre-activities and post-activities. As an initial activity, the teacher usually asks students to fill out the attendance list. At the same time, the temporary activities provided by the teacher are watching videos related to learning topics, discussing, doing assignments, and reading the learning materials provided. For post activities, the teacher gives instructions to students to have discussions or ask questions even after class hours. However, from the five observations made, post-activity was only found in observation 2 . In other observations, the teacher rarely did post-activity. Teachers rarely provide overall feedback to students or stimulate students to conclude learning. By using a classification table, the online learning activities assigned by the teacher are analyzed whether they support the SDL component or not. SDL components and indicators used to classify activities are derived from the theory (Tan \& Koh, 2014). The following table shows the classification.

Table 4 shows 2 SDL components with 4 SDL indicators that can be identified from the five activities assigned by the teacher during the online teaching and learning process. The first activity is asking students to do assignments. This activity puts forward the component of "developing a sense of belonging in students in learning" and fulfills the indicator of "providing students autonomy in designing assignments." In carrying out this activity, the teacher provides opportunities for students to manage resources for their assignments. Once, the teacher also invites students to determine the form of their assignments. It suggests that teachers assist students in developing SDL by setting less prescriptive ground rules about task design (Alonderienė \& Suchotina, 2017; Tan \& Koh, 2014; Yuli Asni, 2019).

Table 5. Online Learning Activities Assigned by the Teacher that Promote SDL

\begin{tabular}{lllc}
\hline $\begin{array}{c}\text { SDL Components } \\
\text { by Tan and Koh } \\
(\mathbf{2 0 1 4 )}\end{array}$ & Indicators & $\begin{array}{c}\text { Activities Assigned by } \\
\text { Teacher that Reflect } \\
\text { SDL Components }\end{array}$ & Occurrence \\
\hline $\begin{array}{l}\text { Developing } \\
\text { students' ownership }\end{array}$ & $\begin{array}{l}\text { a. Providing learners' } \\
\text { autonomy in task } \\
\text { design }\end{array}$ & Doing an assignment & 3 \\
& & &
\end{tabular}




\begin{tabular}{|c|c|c|c|}
\hline $\begin{array}{c}\text { SDL Components } \\
\text { by Tan and Koh } \\
(2014) \\
\end{array}$ & Indicators & $\begin{array}{c}\text { Activities Assigned by } \\
\text { Teacher that Reflect } \\
\text { SDL Components } \\
\end{array}$ & Occurrence \\
\hline \multirow[t]{3}{*}{ of learning } & $\begin{array}{l}\text { d. Involving students in } \\
\text { identifying learning } \\
\text { gaps }\end{array}$ & - & - \\
\hline & $\begin{array}{l}\text { e. Facilitating students' } \\
\text { investigative inquiry, } \\
\text { goal setting, and }\end{array}$ & $\begin{array}{l}\text { Watching video related } \\
\text { to the learning topic }\end{array}$ & 2 \\
\hline & planning & $\begin{array}{l}\text { Reading learning } \\
\text { material provided by the } \\
\text { teacher }\end{array}$ & 1 \\
\hline \multirow{2}{*}{$\begin{array}{l}\text { Developing } \\
\text { students' } \\
\text { management and } \\
\text { self-monitoring }\end{array}$} & $\begin{array}{l}\text { c. Providing scaffolds } \\
\text { for students' self- } \\
\text { monitoring }\end{array}$ & $\begin{array}{l}\text { Doing a discussion } \\
\text { regarding the learning } \\
\text { material }\end{array}$ & 1 \\
\hline & $\begin{array}{l}\text { d. Monitoring students' } \\
\text { learning and } \\
\text { providing just-in-time } \\
\text { assistance }\end{array}$ & $\begin{array}{l}\text { Asking questions even } \\
\text { outside the lesson hour }\end{array}$ & 1 \\
\hline \multirow{3}{*}{$\begin{array}{l}\text { Providing } \\
\text { opportunity for the } \\
\text { students to extent } \\
\text { their learning }\end{array}$} & $\begin{array}{l}\text { d. Engaging the students } \\
\text { in reflection of } \\
\text { learning }\end{array}$ & - & - \\
\hline & $\begin{array}{l}\text { e. Engaging the } \\
\text { students' prior } \\
\text { knowledge }\end{array}$ & - & - \\
\hline & $\begin{array}{l}\text { f. Allowing the students } \\
\text { to make connections } \\
\text { of what they learn in } \\
\text { and out of school }\end{array}$ & - & - \\
\hline
\end{tabular}

The second activity is watching videos related to learning materials. This activity presents a component of "developing a sense of belonging to students in learning." Meanwhile, the relevant indicators of this activity are "facilitating student investigation inquiry, goal setting, and planning. Teachers are considered to facilitate students' investigative inquiry because the learning materials provided by the teacher act as the main learning resource that can guide students in finding other resources they need on their own (Agustuna, Herlina, \& Faridah, 2019; Darmadi, 2015; Tan \& Koh, 2014). The same thing also happened in the third activity, asking students to read the learning material provided. In the fourth activity, the components that can be identified are "developing student selfmonitoring and self-management" with the indicator "providing scaffolds for student selfmonitoring." It has to do with feedback and clarification given by the teacher and also questions and answers generated by students. Through discussion activities, students can assess their understanding and decide what next learning steps they should take, which means students can monitor their learning (Edriati, Anggraini, \& Siska, 2015; Lailiyah \& Wulansari, 2017).

The fifth activity noted as promoting the SDL component is asking questions even outside of class hours. Its component is "developing student self-monitoring and selfmanagement." Furthermore, the indicators that are met are "monitoring student learning and providing just-in-time assistance." Although students are encouraged to be independent, teachers need to monitor learning so that difficulties faced by students can be identified and 
solved (Kristiantari, 2015; Tan \& Koh, 2014; Wahyono, Husamah, \& Budi, 2020). Solutions or feedback provided by the teacher through this activity can improve self-management and self-monitoring. In addition, no activity reflects the third SDL component. This component is referred to as providing opportunities for students to expand their learning. As shown in Table 4, this component indicator is related to learning reflection, which generally lies in the last segment of learning. From the findings of this study, it can be concluded that teachers perceive SDL positively. Teachers are aware of the importance of SDL and feel that they often carry out learning activities that promote SDL. Furthermore, he assessed the impact of SDL on students. It is in line with previous research showing that EFL teachers in Indonesia have a positive principle of independent learning closely related to SDL. (Hawkins, 2018; Khotimah et al, 2019; Yuzulia, 2020). Teachers recognize that self-directed learning emphasizes the active role of students in managing their learning and demonstrates that independent learning benefits student learning (Bharathi, 2014; Boyadzhieva, 2016). In addition, teachers feel that they have had some attempts to expose students to independent learning.

The observations revealed that teachers rarely do pre and post-activities that are very important for student learning in the online teaching and learning process. Teachers mostly only provide learning materials and ask students to do assignments as temporary activities. In addition, overall feedback on learning and individual feedback on student work is rarely provided by teachers. Teachers must be creative and innovative in providing activities to students in an online learning environment (Atmojo \& Nugroho, 2020; Wulandari, Sudatha, \& Simamora, 2020). Because creative and innovative activities can significantly increase student participation in the learning process. Furthermore, teachers need to provide constant feedback and communication in online learning because it can motivate students to follow the learning (Amiti, 2020; Khayati et al, 2020). It can be said that teachers must improve the implementation of online learning so that the learning process runs better and students can get meaningful learning.

The application of SDL has not been maximized. It is in line with previous research, which showed that EFL teachers who were learning participants did not apply adequate strategies to support students' independence in learning (Munaweroh, 2020; Yuzulia, 2020). Teachers tend to use classical strategies that do not focus on student-centered learning. It means that improvements in facilitating SDL, especially in online learning, must be made by teachers aware of the importance of SDL in the 21st century. In addition, there is an implied inconsistency between the teacher's perception and the real situation in the classroom. In the questionnaire, most teachers stated that they often carry out learning activities that reflect SDL and agree that SDL is very important. EFL teachers are hesitant to involve students in methodological decisions related to learning content or assignments, although they state that student autonomy is an important aspect of language learning. However, Ariebowo (2021) states that in this 21 st-century era, teachers must stop doubting and belittling students' ability to manage their autonomy. As a result, teachers and school authorities need to develop the most appropriate curriculum and assignments to encourage students to be more independent and independent in learning.

Regarding students' autonomy, from observations, it was found that students can follow the teacher's instructions in studying the material, doing assignments, and carrying out discussions. In doing the assignment, students managed to find their resources. They can also determine the form of their assignments based on the choices given by the teacher. Meanwhile, in carrying out the discussion, students seemed eager to produce questions and answers related to the learning material that had been studied previously. It can be said that several learning activities carried out by teachers identified as having SDL components contribute to the development of student learning independence. The application of the SDL 
strategy can foster student independence in learning (Curry et al., 2017; Gharti, 2019). The development of the independence of students can be shown by the capacity of students to make the right choices and decisions and to interact with students (Benson,2016).

\section{Conclusion}

From the study results, it can be concluded that English teachers consider themselves "knowledgeable" about SDL content knowledge and "anticipate" in applying SDL. In addition, teachers feel the impact of SDL "influence" on students. In the online teaching and learning process, the activities provided by the teacher include studying the material provided, doing assignments, and conducting discussions. This activity is categorized as a temporary activity. Teachers rarely do pre-activities and post-activities. From the online learning activities provided by the teacher, there are two components of SDL that can be identified.

\section{References}

Agustuna, N. E., Herlina, R., \& Faridah, D. (2019). Corrective Feedback on Pronunciation Errors: Teacher's Perception and EFL High School Students' Self-Reflection. Journal Of English Education And Teaching, 3(3). https://doi.org/https://doi.org/10.33369/jeet.3.3.311-327.

Alonderienè, R., \& Suchotina, N. (2017). The Impact of Self-directed Learning on Work Performance of Lawyers. Organizations And Markets In Emerging Economies, 8(2). https://doi.org/https://doi.org/10.15388/omee.2017.8.2.14185.

Amiti, F. (2020). Synchronous and asynchronous E-learning. European Journal of Open Education and E-Learning Studies, 50-70. https://doi.org/10.46827/ejoe.v5i2.3313.

Andrian, \& Rusman. (2019). Implementasi Pembelajaran Abad 21 Dalam Kurikulum 2013. Jurnal Penelitian Ilmu Pendidikan, 12(1). https://doi.org/https://doi.org/10.21831/jpipfip.v12i1.20116. 14-23.

Ariebowo, T. (2021). Autonomous learning during COVID-19 pandemic: Students , objectives and preferences. Journal of Foreign Language Teaching and Learning, 6(1), 56-77. https://doi.org/https://doi.org/10.18196/ftl.v6i1.10079.

Atmojo, A. E. P., \& Nugroho, A. (2020). EFL classes must go online! Teaching activities and challenges during COVID-19 pandemic in Indonesia. Register Journal, 13(1), 49-76. https://doi.org/https://doi.org/10.18326/rgt.v13i1.49-76.

Benson, P. (2016). Language learner autonomy: Exploring teachers' perspectives on theory and practice. In Language learner autonomy: Teachers' beliefs and practices in Asian contexts (pp. xxxiii-xliii). https://doi.org/http://dx.doi.org/10.5746/LEiA/LA_Asia.

Bharathi, P. (2014). Self - directed learning and learner autonomy in English language teacher education : Emerging trends. International Journal For Teachers of English, 4(1), 1-9.

Boyadzhieva, E. (2016). Learner-centered Teaching and Learner Autonomy. Procedia Social and Behavioral Sciences, 232, 35-40. https://doi.org/10.1016/j.sbspro.2016.10.008.

Brandt, W. C. (2020). Measuring student success skills: A review of the literature on selfdirected learning. Dover, NH: National Center for the Improvement of Educational Assessment.

Curry, N., Mynard, J., Noguchi, J., \& Watkins, S. (2017). Evaluating a self-directed language learning course in a Japanese university. International Journal of Self-Directed 
Learning, 14(1), 17-36.

Daggol, G. D. (2017). Lifelong learning: Not a 21st century, but an omnitemporal skill. International Journal of Social Humanities Sciences Research (JSHSR), 4(12), 12541267. https://doi.org/10.26450/jshsr.207.

Darmadi, H. (2015). Tugas, Peran,Kompetensi, dan Tanggung Jawab Menjadi Guru Profesional. Jurnal Edukasi, https://doi.org/http://dx.doi.org/10.31571/edukasi.v13i2.113.

Devi, S., Bhat, Ks., Ramya, S., Ravichandran, K., \& Kanungo, R. (2016). Self-directed learning to enhance active learning among the 2nd -year undergraduate medical students in Microbiology: An experimental study. Journal of Current Research in Scientific Medicine, 2(2), 80-83. https://doi.org/10.4103/2455-3069.198379.

Durnali, M. (2020). The effect of self-directed learning on the relationship between selfleadership and online learning among university students in Turkey. Tuning Journal for Higher Education, 8(1), 129-165. https://doi.org/http://dx.doi.org/10.18543/tjhe8(1)-2020pp129-165 Received.

Edriati, S., Anggraini, V., \& Siska, M. (2015). Efektivitas Model Jigsaw Disertai Penilaian Diskusi Untuk Meningkatkan Kemampuan Matematis Mahasiswa. Cakrawala Pendidikan, 1(2). https://doi.org/https://doi.org/10.21831/cp.v2i2.4833.

Geng, S., Law, K. M. Y., \& Niu, B. (2019). Investigating self-directed learning and technology readiness in blending learning environment. International Journal of Educational Technology in Higher Education, 16(1), 17. https://doi.org/10.1186/s41239-019-0147-0.

Gharti, L. (2019). Self-directed learning for learner autonomy: Teachers' and students' perceptions. Journal of NELTA Gandaki, 1, 62-73. https://doi.org/10.3126/jong.v1i0.24461.

Hanik, E. U. (2020). Self directed learning berbasis literasi digital pada masa pandemi covid19 di Madrasah Ibtidaiyah. ELEMENTARY: Islamic Teacher Journal, 8(1), 183. https://doi.org/10.21043/elementary.v8i1.7417.

Hawkins, M. W. (2018). Self-directed learning as related to learning strategies, selfregulation, and autonomy in an English language program: A local application with global implications. Studies in Second Language Learning and Teaching, 8(2), 445469. https://doi.org/10.14746/ss1lt.2018.8.2.12.

Hill, M., Peters, M., Salvaggio, M., Vinnedge, J., \& Darden, A. (2020). Implementation and evaluation of a self-directed learning activity for first-year medical students. Medical Education Online, 25(1), 1-10. https://doi.org/10.1080/10872981.2020.1717780.

Hirschman, K., \& Wood, B. (2018). 21st century learners: Changing conceptions of knowledge, learning and the child. The New Zealand Annual Review of Education, 23(June), 20. https://doi.org/10.26686/nzaroe.v23i0.5280.

Humaira, S. A., \& Hurriyah, I. A. (2018). Students 'perspectives towards self-directed learning out of classroom. Advances in Social Science, Education and Humanities Research, 145, 7-11. https://doi.org/10.2991/iconelt-17.2018.2.

Khayati, N. A., Muna, F., Oktaviani, E. D., Hidayatullah, \& Fauzan, A. (2020). Peranan Guru Dalam Pendidikan Inklusif Untuk Pencapaian Program Tujuan Pembangunan Berkelanjutan (SDG's). Komunikasi Pendidikan, 4(1). https://doi.org/https://doi.org/10.32585/jkp.v4i1.440.

Khotimah, K., Widiati, U., Mustofa, M., \& Faruq Ubaidillah, M. (2019). Autonomous English learning: Teachers' and students' perceptions. Indonesian Journal of Applied Linguistics, 9(2), 371-381. https://doi.org/10.17509/ijal.v9i2.20234.

Kristiantari, M. R. (2015). Analisis kesiapan guru sekolah dasar dalam mengimplementasikan pembelajaran tematik integratif menyongsong kurikulum 2013. JPI (Jurnal 
Pendidikan Indonesia), 3(2). https://doi.org/http://dx.doi.org/10.23887/jpiundiksha.v3i2.4462.

Lailiyah, \& Wulansari. (2017). Peningkatan Keterampilan Berbicara Melalui Metode Diskusi Kelompok Model Tanam Paksa Siswa Kelas X Pemasaran 1 SMK PGRI 2 Kediri. JP (Jurnal Pendidikan), 1(2), 166-173. https://doi.org/http://dx.doi.org/10.26740/jp.v1n2.p166-173..

Munaweroh, R. (2020). The use of English UKBM to support independent learning in senior high school. Research On English Language Teaching in Indonesia, 8(3), 1-10.

Shaalan, I. E.-N. A. W. (2019). Remodeling teachers' and students' roles in self-directed learning environments: The case of Saudi Context. Journal of Language Teaching and Research, 10(3), 549-556. https://doi.org/10.17507/jltr.1003.19.

Sugiyono. (2015). Metode penelitan kuantitatif, kualitatif dan R\&D. Bandung: Alfabeta.

Suryadewi, N. K. A., Wiyasa, I. K. N., \& Sujana, I. W. (2020). Kontribusi Sikap Mandiri dan Hubungan Sosial Terhadap Kompetensi Pengetahuan IPS. MIMBAR PGSD Undiksha, 8(1), 29-39. https://doi.org/http://dx.doi.org/10.23887/jjpgsd.v8i1.24576.

Tan, L., \& Koh, J. H. (2014). Self-directed Learning: Learning in the 21st century. Singapore: Singapore Ministry of Education.

Timpau, C. (2015). Importance of self-directed learning. Logos Universality Mentality Education Novelty. Section: Social Sciences, 04(01), 37-49. https://doi.org/10.18662/lumenss.2015.0401.03.

Tjakradidjaja, F. A., Prabandari, Y. S., Prihatiningsih, T. S., \& Harsono, H. (2016). The role of teacher in medical student self-directed learning process. Journal of Education and Learning (EduLearn), 10(1), 78-84. https://doi.org/10.11591/edulearn.v10i1.2992.

Van der Walt, H. (2016). The feasibility of grafting self-directed learning theory onto the capability theory. In E. Ments \& I. Oosthuizen (Eds.), Self directed learning research (pp. 1-34). https://doi.org/http://dx.doi.org/10.4102/ aosis.2016.sdlr14.01.

Van Woezik, T., Reuzel, R., Koksma, J., \& Serpa, S. (2019). Exploring open space: A selfdirected learning approach for higher education. Cogent Education, 6(1), 1-22. https://doi.org/10.1080/2331186X.2019.1615766.

Vu, H. Y., \& Shah, M. (2016). Vietnamese students' self-direction in learning English listening skills. Asian Englishes, 18(1), 53-66. https://doi.org/10.1080/13488678.2015.1136104.

Wahyono, P., Husamah, H., \& Budi, A. S. (2020). Guru profesional di masa pandemi COVID-19: Review implementasi, tantangan, dan solusi pembelajaran daring. Jurnal Pendidikan Profesi Guru, 1(1), 51-65. https://doi.org/https://doi.org/10.22219/jppg.v1i1.12462.

Wulandari, Sudatha, \& Simamora. (2020). Pengembangan Pembelajaran Blended Pada Mata Kuliah Ahara Yoga Semester II di IHDN Denpasar. Jurnal Edutech Undiksha, 8(1), 1-15. https://doi.org/http://dx.doi.org/10.23887/jeu.v8i1.26459.

Yuli Asni. (2019). Pembinaan Kedisiplinan Dalam Proses Belajar Mengajar Terhadap Etos Kerja Mandiri Guru Sd Negeri 16 Bathin Solapan. Jurnal Pajar, 3(3). https://doi.org/https://doi.org/10.33578/pjr.v3i3.7252.

Yuzulia, I. (2020). EFL tecahers' perceptions and stratgeies in inplementing learner autonomy. Journal of Linguistics and Language Teaching, 6(1), 36-54. https://doi.org/http://dx.doi.org/10.29300/ling.v6i1.2744.

Zhu, M., Bonk, C. J., \& Doo, M. Y. (2020). Self-directed learning in MOOCs: Exploring the relationships among motivation, self-monitoring, and self-management. Educational Technology Research and Development, 68(5), 2073-2093. https://doi.org/10.1007/s11423-020-09747-8. 